\title{
CHEMICAL COMPOSITION AND TERMITICIDAL ACTIVITY OF Khaya ivorensis STEM BARK EXTRACTS ON WOODS
}

\author{
Gabriel Adetoye Adedeji ${ }^{1,}$, Olukayode Yekin Ogunsanwo ${ }^{2}$, Funmilayo Sarah Eguakun ${ }^{1,}$ \\ Taiwo Olayemi Elufioye
}

In memoriam of Dr. Thomas C. MANNES

\begin{abstract}
The genus Khaya is extractives rich, but the extractives in the stem bark are among the most abundant, accessible and utilised materials in Nigeria. These extractives are of considerable interest for wood protection because of their pesticidal properties. In this study, the chemical constituents of Khaya ivorensis stem bark and their termiticidal activity were investigated on Triplochiton scleroxylon and Vitex doniana woods. Spectrophoto-metric and Forlin-Ciocalteu analyses showed that Khaya ivorensis stem bark contained total: alkaloids $38,98 \pm 0,02 \mathrm{mg} / \mathrm{g}$, flavonoids $0,37 \pm 0,02 \mathrm{mg} / \mathrm{g}$, phenol 50,62 $\pm 0,11$ $\mathrm{mg} / \mathrm{g}$, saponins $156,31 \pm 0,76 \mathrm{mg} / \mathrm{g}$, and tannins $59,95 \pm 0,54 \mathrm{mg} / \mathrm{g}$. Field tests demonstrated that the extract from Khaya ivorensis stem bark had significant termiticidal activity at tested concentrations compared to the control. The results indicated that Khaya ivorensis stem bark has potential as a natural agent for termite control.
\end{abstract}

Keywords: Bioactive compounds, chemical analysis, phytochemical extracts, Triplochiton scleroxylon, Vitex doniana, wood treatability.

\section{INTRODUCTION}

The genus Khaya (Family: Meliaceae) is rich in extractives throughout the plant, but these extractives are primarily concentrated in the stem bark (Olayinka et al.1992, Iwu 1993). These extractives are of considerable interest for wood protection because of their indigenously known pesticidal properties (Ademola et al. 2004, Agbedahunsi et al. 2004). Khaya ivorensis (Oganwo, Yoruba Nigeria) and its congeners have a long traditional history of pesticidal uses including control of human intestinal roundworm infestations (antihelminths) (Stephen et al. 2009, Lawal et al. 2010, Olusola and Oyeleke 2015 ) and protective activities against skin diseases usually caused by fungi and bacteria (Olusola and Oyeleke 2015, Adedeji 2016). They have also been used to protect stored cassava/yam chips against pests (Babajide et al. 2007, Loko et al. 2013).

Leaf extracts from $K$. ivorensis showed excellent antifungal activities against stored foods spoilage fungi (Babajide et al. 2008, Oladimeji et al. 2013). The root has been reported to cure sexually transmitted diseases (Kayode et al. 2009). Limonoids isolated from K. senegalensis fruits, and seed oil exhibited strong biological activity against the plant pathogenic fungus Botrytis cinerea Pers (Abdelgaleil et al. 2004) and cattle ticks (Boophilus decoloratus) (Choudhury and Boshe 2013). Specifically, limonoids from $K$. ivorensis seed/fruit and stem bark exerted antifeeding, antifungal, antibacterial, antitrypanosomal and antitumor activities (Vanucci et al. 1992, Abdelgaleil and ElAswad 2005, Abdelgaleil et al. 2005, Zhang et al. 2009, Ji et al. 2014). Ewete and Bamigbola

\footnotetext{
${ }^{1}$ Department of Forestry and Wildlife Management, University of Port Harcourt, Port Harcourt. Nigeria.

${ }^{2}$ Department of Forest Resources Management, University of Ibadan, Ibadan. Nigeria.

${ }^{3}$ Department of Pharmacognosy, University of Ibadan, Ibadan. Nigeria. .

•Corresponding author: gabriel.adedeji@uniport.edu.ng

Received: 18.01.2017 Accepted: 22.01.2018
} 
(1998) reported that a crude extract of $K$. ivorensis stem bark at 500-1000ppm significantly reduced Callosobruchuchus maculatus emergence on Bambara groundnut own several generations. However, very little is known about the pesticidal activity of $K$. ivorensis against wood-degrading agents. In this study, the chemical composition of $K$. ivorensis stem bark extractives was quantified and termiticidal activity on Triplochiton scleroxylon and Vitex doniana wood test blocks was investigated under field conditions.

\section{MATERIAL AND METHODS}

\section{Plant collection and extraction}

The stem bark of $K$. ivorensis was collected from Masanwo/Adedeji Village via Imeko, Ogun State, Nigeria and air-dried for three months. The air-dried materials were milled before $500 \mathrm{~g}$ samples $(\mathrm{n}=4)$ were separately extracted in $2,5 \mathrm{~L}$ of $70 \%$ ethanol with constant shaking for five days. The ethanol extracts were filtered and concentrated on a rotary evaporator to dryness. The percentage yield was evaluated following the formula (Equation 1) thus:

$$
\text { Percentage yield }=\frac{\text { Average dry weight of concentrated extracts }}{\text { Average weight of the air }- \text { dried milled samples }} \times 100
$$

\section{Quantifications of chemicals in Khaya ivorensis stem bark (KISB) extract}

Concentrations of alkaloids, flavonoids, phenol, saponins and tannins in the KISB extract were quantitatively analysed by using Spectrophoto-metric and Forlin-Ciocalteu methods (Hiai et al. 1976, Padmaja 1989, Singh et al. 2004, Chan et al. 2007, Kale et al. 2010). All the quantifications were performed in duplicate and presented as mean values $(\mathrm{n}=2) \pm$ Standard Deviation $(\mathrm{SD}) \mathrm{in} \mathrm{mg} / \mathrm{g}$.

\section{Procedures}

Briefly, $25 \mathrm{~mL}$ of methanol was added to $0,5 \mathrm{~g}$ of sample contained in a covered $50 \mathrm{~mL}$ centrifuge tube which was shaken continuously for 1 hour at room temperature (Chan et al. 2007). The mixture was centrifuged at $3000 \mathrm{rpm}$ for $10 \mathrm{~min}$, and then the supernatant was collected and stored at $-20^{\circ} \mathrm{C}$ until the analysis was done.

\section{Quantification of total alkaloids content (TAC)}

The total alkaloid contents in the samples were measured using the 1,10-phenanthroline method described by Singh et al. (2004) with slight modifications. A $100 \mathrm{mg}$ sample powder was extracted in $10 \mathrm{~mL}$ of $80 \%$ ethanol. This was centrifuged at $5000 \mathrm{rpm}$ for $10 \mathrm{~min}$. The supernatant was collected and used for further estimation of total alkaloids. The reaction mixture contained $1 \mathrm{~mL}$ plant extract, 1 $\mathrm{mL}$ of $0,025 \mathrm{M} \mathrm{FeCl}$ in $0,5 \mathrm{M} \mathrm{HCl}$ and $1 \mathrm{~mL}$ of $0,05 \mathrm{M}$ of 1,10 -phenanthroline in ethanol. The mixture was incubated for 30 minutes in a hot water bath at $70 \pm 2^{\circ} \mathrm{C}$. Absorbance of the red coloured complex was measured at $510 \mathrm{~nm}$ against a reagent blank. Alkaloid contents were estimated against a standard curve of qui-nine $(0,1 \mathrm{mg} / \mathrm{mL}, 10 \mathrm{mg}$ dissolved in $10 \mathrm{~mL}$ ethanol and diluted to $100 \mathrm{~mL}$ with distilled water). The values were expressed as g. $100 \mathrm{~g}-1$ of dry weight.

\section{Quantification of total flavonoids content (TFC)}

TFC was determined by the aluminium chloride method as reported by Kale et al. (2010). A sample $(0,5 \mathrm{~mL})$ of the extract was dispensed into a test tube along with $1,5 \mathrm{~mL}$ of methanol $0,1 \mathrm{~mL}$ of aluminium chloride $(10 \%) 0,1 \mathrm{~mL}$ of $1 \mathrm{M}$ potassium acetate and $2,8 \mathrm{~mL}$ of distilled water. The reaction mixture was mixed and allowed to stand at room temperature for 30 minutes before absorbance was read at $514 \mathrm{~nm}$. TFC was expressed as quercetin equivalent $(\mathrm{QE})$ in $\mathrm{mg} / \mathrm{g}$ material. 


\section{Quantification of total phenolic content (TPC)}

The total phenolic content of the extracts was determined according to the Folin-Ciocalteu method (Chan et al. 2007). Briefly, $300 \mu \mathrm{L}$ of extract was dispensed into a test tube (in triplicates) along with $1,5 \mathrm{~mL}$ of Folin-Ciocalteu reagent (diluted 10 times with distilled water), followed by $1,2 \mathrm{~mL}$ of $\mathrm{Na} \mathrm{CO}$ solution $(7,5 \mathrm{w} / \mathrm{v})$. The reaction mixture was mixed and allowed to stand for $30 \mathrm{~min}$ at room teminerăture before the absorbance was measured at $765 \mathrm{~nm}$ against a blank prepared by dispensing $300 \mu \mathrm{L}$ of distilled instead of sample extract. TPC was expressed as Gallic acid equivalent (GAE) in $\mathrm{mg} / \mathrm{g}$ material.

\section{Quantification of total saponins content (TSC)}

Total saponins (TS) were determined using a modification of the method of Hiai et al. (1976) as described by Makkar et al. (2007). The sample (0,5 g) was extracted with $25 \mathrm{~mL}$ of $80 \%$ aqueous methanol on a mechanical shaker for 2 hour, after which the contents of the tubes were centrifuged for $10 \mathrm{~min}$ at $3000 \mathrm{rpm}$. An aliquot $(0,25 \mathrm{~mL})$ of the supernatant was added to $0,25 \mathrm{~mL}$ vanillin reagent $(8 \%$ vanillin in ethanol) and $2,5 \mathrm{~mL}$ of $72 \%$ aqueous $\mathrm{H} \mathrm{SO}$ in a test tube. The reaction mixtures were heated in a water bath at $60{ }^{\circ} \mathrm{C}$ for $10 \mathrm{~min}$. The tubes were cooled on ice for $4 \mathrm{~min}$ and then acclimatized to room temperature. Absorbance was measured in a Uv/Visible spectrophotometer at $544 \mathrm{~nm}$. Diosgenin was used as a standard and the results obtained were expressed as mg diosgenin equivalent per $\mathrm{g}$ of sample dry matter.

\section{Quantification of total tannin content (TTC)}

Tannin content of samples was determined according to the method of Padmaja (1989). Sample $(0,1 \mathrm{~g})$ was extracted with $5 \mathrm{~mL}$ of acidified methanol $(1 \% \mathrm{HCl}$ in methanol $)$ at room temperature for 15 minutes. The mixture was centrifuged at $3000 \mathrm{rpm}$ for 20 minutes, $0.1 \mathrm{~mL}$ of the supernatant was added to $7,5 \mathrm{~mL}$ of distilled water $0,5 \mathrm{~mL}$ of Folin-Denis reagent, $1 \mathrm{~mL}$ of $35 \%$ sodium carbonate solution and diluted to $10 \mathrm{ml}$ with distilled water. The mixture was shaken well, kept at room temperature for 30 min and absorbance was measured at $760 \mathrm{~nm}$. A blank was prepared with water instead of the extract. Tannin content was expressed as tannic acid equivalent (TAE) in $\mathrm{mg} / \mathrm{g}$ material.

\section{Wood block preparation}

Small wood samples $(2 \mathrm{~cm} \times 2 \mathrm{~cm} \times 6 \mathrm{~cm})$ were processed from unblemished 22 year old Triplochiton scleroxylon and 28 year old Vitex doniana trees' bolts. Wood samples were oven dried at $103 \pm 2{ }^{\circ} \mathrm{C}$ to constant weight (ASTM D-1413-2007) and weighed $\left(\mathrm{W}_{0}\right)$. The samples were then kept in air-tight bags prior to use. Thereby mix samples of each wood species containing mixtures of sapwood and heartwood were selected for tests.

\section{Test formulations development and wood treatments}

The extract was diluted in $1 \mathrm{~L}$ of $70 \%$ ethanol to $5 \%, 10 \%, 15 \%$, and $20 \%$ of $(26,7 \mathrm{~g}$ or $5,3 \%$ yield) along with solvent alone and a control was included. The oven dried wood samples ( 18 replicates) were then soaked in their respective formulations for 3 days. Then weight gain $\left(\mathrm{W}_{2}\right)$ was used to calculate the net absorption and retention.

\section{Field exposure test}

Termite resistance of the treated and untreated wood samples was evaluated according to procedures used by Lenz et al. (2003), Lenz et al. (2011), Asamoah et al. (2014). The termite field test was carried out at Latitude $7^{\circ} 44^{\prime} 29^{\prime \prime}$ and $7^{\circ} 44^{\prime} 31^{\prime \prime} \mathrm{N}$ and Longitude $3^{\circ} 89^{\prime} 75^{\prime \prime}$ and $3^{\circ} 89^{\prime} 77^{\prime \prime} \mathrm{E}$ within the University of Ibadan, Nigeria. The area is a humid agro-ecological zone (Ajayi et al. 2012) and is known to be perennially infested with variety of termites. The area experiences high relative humidity and generally two rainfall maxima regimes during the rainfall period of March to October with an average of $1230 \mathrm{~mm}$ per annum. The mean annual temperatures range between $22^{\circ} \mathrm{C}$ and $31^{\circ} \mathrm{C}$ 
and relative humidity ranges between $57 \%$ and $99 \%$ (Oshunsanya 2013). The soil type is an Alfsol formed from the basement complex rocks (Oshunsanya 2013). Termite's infestation in the area was very severe, essentially subterranean types (such as Amitermes evuncifer, Macrotermes bellicosus, and Odontotermes spp (Adedeji 2016)) which have variable foraging specificity ranging from damp to dry woods.

From eighteen treated blocks each of T. scleroxylon (TS) and $V$. doniana (VD) samples per treatment, six replicates were used. The TS and VD samples treated with the same extract concentration were placed side by side horizontally and buried on the topsoil level spaced at $1 \mathrm{~m}$ apart from each different treatment wood blocks. After six months, the test samples were carefully exhumed from the field, renumbered, scrubbed and washed to remove all the soil particles, dried at room temperature and finally oven dried for 22 hours at $103 \pm 2^{\circ} \mathrm{C}$. From the oven dry weight after the treatment and final ovendried weight after the field test, the weight loss $\%$ and termiticidal activity of the formulations were calculated with the reference to the control samples using the standard formula (Equation 2).

$$
\text { Wood block weight loss } \%=\frac{\left[\left(W_{2}-W_{3}\right)\right]}{W_{2}} \times 100
$$

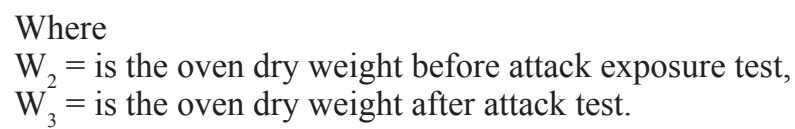

\section{Statistical data analysis}

Data from the experiments were analysed using analysis of variance (ANOVA) and Least Significant Difference (LSD) at $p<0,05$. All results were expressed as means \pm Standard Deviation (SD).

\section{RESULTS AND DISCUSSION}

\section{Percentages extractive yield}

Khaya ivorensis stem bark extract $(5,33 \pm 0,02 \%)$ was obtained as very fine glassy/shinning reddishbrown pellets. Phytochemicals, including phenolic content are known to influence the rate of wood degradation by termites (Syofuna et al. 2012, Kadir 2017). The extracts contained appreciable amounts of: saponins $(156,31 \pm 0,76 \mathrm{mg} / \mathrm{g})$, tannins $(59,95 \pm 0,54 \mathrm{mg} / \mathrm{g})$, phenol $(50,62 \pm 0,11 \mathrm{mg} / \mathrm{g})$, alkaloids $(38,98 \pm 0,02 \mathrm{mg} / \mathrm{g})$, and flavonoids $(0,37 \pm 0,02 \mathrm{mg} / \mathrm{g})$. KISB extract yield was much lower than $13 \%$ obtained using hot water (Tepongning et al. 2011, Tepongning et al. 2013) in Cameroon. High extract yields were also obtained from $K$. senegalensis leave with methanol $(20,5 \%)$ or aqueous extraction $(17,4 \%)$ in Sudan (Satti and Elamin 2012). This variability may reflect the variability in solvents used and potential the moisture levels at which the yields were determined. The glassy/shining appearance of the extract suggested that KISB might contain silica. The KISB extract colour correlated well with the previous studied (Taiwo and Ogunbodede 1995, Falodun et al. 2009, Stephen et al. 2009, Tepongning et al. 2011).

Chemical analyses showed with total saponins content being most copious. Previously, many studies on K. ivorensis chemicals have been documented (Adesogan and Taylor 1970, Adesida et al. 1971, Taylor 1977, Vanucci et al. 1992, Abdelgaleil et al. 2005, Zhang et al. 2009, Ji et al. 2014). These studies were however focused on specific compounds mainly limonoids. Taiwo and Ogunbodede (1995) documented an increasing extractable tannin (\%) contents from reducing $K$. ivorensis bark ground particle sizes for development of adhesives. Recently, Adeyemi et al. (2014) qualitatively documented among others, the presence of saponins, tannins and flavonoids in K. ivorensis stem bark. The highest total amounts of saponins found in this study agreed with the findings of Ejikeme et al. (2014) that $K$. 
ivorensis wood heavily contained saponins. While plants produce varying chemical compounds as part of their normal routine metabolic activities, the high quantities of total saponins $>$ tannins $>$ phenol $>$ alkaloids contents found in this study confirmed the extractives richness of KISB.

\section{Treatability}

The two tropical test wood species showed no significant variability at the level of treatability in terms of KISB extractives uptake (absorption) and retention (Table 1). VD absorbed and retained extractives more than TS wood samples. The slight differences were likely the variations in chemical composition, cell wall organisation and density (Khazaei 2008). Previous studies have documented absorption of $24,9 \mathrm{~kg} / \mathrm{m}^{3}$ (Omole and Onilude 2000) $54,86-64,90 \mathrm{~kg} / \mathrm{m}^{3}$ (Olajuyigbe et al. 2010) $70,37-117,13 \mathrm{~kg} / \mathrm{m}^{3}$ (Ogunsanwo and Adedeji 2010) and 190,1-206,8 kg/m³ (Emerhi et al. 2015) for T. scleroxylon wood.

Table 1. Means comparison for treatability of woods with extract formulations.

\begin{tabular}{|c|c|c|c|}
\hline \multicolumn{2}{|c|}{ Absorption } & \multicolumn{2}{|c|}{ Retention } \\
\hline Parameters & Mean $\left(\mathrm{kg} / \mathrm{m}^{3}\right)$ & Parameters & Mean $\left(\mathrm{kg} / \mathrm{m}^{3}\right)$ \\
\hline Wood blocks species & & Wood block species & \\
\hline Vitex doniana & $32,15 \pm 15,84^{\mathrm{a}}$ & Vitex doniana & $1,79 \pm 1,56^{\mathrm{a}}$ \\
\hline Triplochiton scleroxylon & $28,88 \pm 18,08^{a}$ & $\begin{array}{l}\text { Triplochiton } \\
\text { scleroxvlon }\end{array}$ & $1,66 \pm 1,71^{\mathrm{a}}$ \\
\hline Extract concentrations & & $\begin{array}{c}\text { Extract } \\
\text { concentrations }\end{array}$ & \\
\hline $15 \%$ & $41,69 \pm 12,62^{\mathrm{a}}$ & $20 \%$ & $3,94 \pm 0,40^{\mathrm{a}}$ \\
\hline $5 \%$ & $40,19 \pm 8,28^{a}$ & $15 \%$ & $3,34 \pm 1,01^{\mathrm{b}}$ \\
\hline $10 \%$ & $37,95 \pm 14,29^{a}$ & $10 \%$ & $2,02 \pm 0,76^{\mathrm{c}}$ \\
\hline $20 \%$ & $36,95 \pm 5,09^{a}$ & $5 \%$ & $1,07 \pm 0,22^{\mathrm{d}}$ \\
\hline $0 \%$ & $26,33 \pm 5,60^{\mathrm{b}}$ & $0 \%$ & $0,00 \pm 0,00^{\mathrm{e}}$ \\
\hline Control & $0,00 \pm 0,00^{\mathrm{b}}$ & Control & $0,00 \pm 0,00^{\mathrm{e}}$ \\
\hline
\end{tabular}

Means with the same alphabet within parameter are not significantly different from each other at $\alpha=0,05$

\section{Termiticidal activity of KISB extract}

Termiticidal activity of KISB extract formulations against field termites on treated and untreated two wood species test samples was assessed and their effectiveness was quantitatively evaluated by the corresponding wood weight loss (WWL) values as presented in Table 2 and Figure 1. In line with the global trend of going back to nature, this study evaluated termiticidal activity of KISB crude extract using established below-ground contact approach on TS and VD woods. Generally, VD wood was more heavily attacked than TS wood while blocks treated with $10 \%, 15 \%$ and $5 \%$ concentrations of the extract showed moderate effectiveness (27\%-31,5\% wood weight loss (WWL)) according BS EN 252 2014 (Table 3) compared to $84,4 \%$ WWL for $20 \%$ concentration and $100 \%$ WWL for both controls. The significant interaction effect showed the severity levels of WWL among the formulations (Figure 1) but $15 \%, 10 \%$, and $5 \%$ indicated moderately effectiveness on both test wood species. The percentage mean WWL (ranges of $27 \%$ to $31,5 \%$ ) for $15 \%, 10 \%$ and $5 \%$ were reflections of remarkably moderate termiticidal activity and such indicated better protection of wood against termites than $54,5 \%$ saving ( $45,5 \%$ weight loss) of stored Sorghum grains treated Khaya senegalensis leaf extract against beetles (Trogoderma granarium) reported in Sudan (Satti and Elamin 2012). This termiticidal property agreed with the reported biological activity of $K$. ivorensis stem bark at 250-1000 ppm against Bambara groundnut weevil, Callosobruchus maculatus (Ewete and Bamigbola 1998). This trend of termiticidal result has a promising conservation implication as little will effect better protection. Amitermes evuncifer, Macrotermes bellicosus, and Odontotermes spp. were the common termites species identified in the study area. However, Amitermes evuncifer was found to be the dominant species degrading the testing blocks under the soil. Termites' attacks were negligible in some but the high numbers of the test blocks were attacked by some soil-inhabiting fungi notable one being strand-forming, like Coniophora olivacea fungus. The additional WWL caused by fungi was likely occasioned by early downpour of rainfall (precipitation) between February and April in the year 2014. 
Table 2. Main effect comparison for wood weight loss caused by termites.

\begin{tabular}{|c|c|}
\hline Parameters & Mean \pm S.D (\%) \\
\hline Wood blocks species & \\
\hline Triplochiton scleroxylon & $59,41 \pm 33,51^{\mathrm{a}}$ \\
\hline Vitex doniana & $65,34 \pm 35,31^{\mathrm{b}}$ \\
\hline Extract concentrations & $27,01 \pm 3,42^{\mathrm{a}}$ \\
\hline $10 \%$ & $31,37 \pm 5,43^{\mathrm{a}}$ \\
\hline $15 \%$ & $31,49 \pm 3,12^{\mathrm{a}}$ \\
\hline $5 \%$ & $84,39 \pm 21,8^{\mathrm{b}}$ \\
\hline $20 \%$ & $100,00 \pm 0,00^{\mathrm{c}}$ \\
\hline $0 \%$ & $100,00 \pm 0,00^{\mathrm{c}}$ \\
\hline Control & \\
\hline
\end{tabular}

Means with the same alphabet within parameter are not significantly different from each other at $\alpha=0,05$

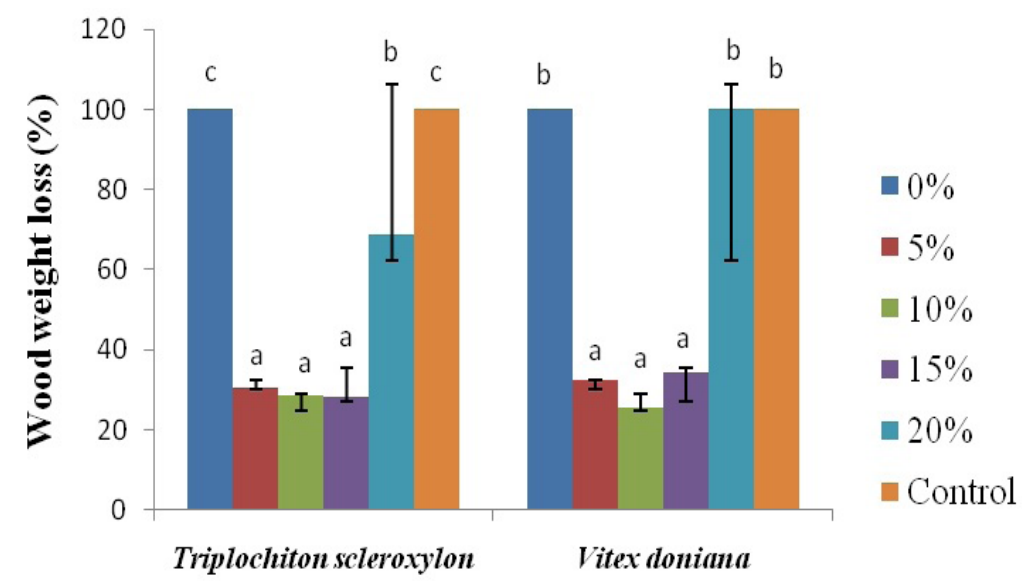

\section{Wood type}

Figure 1. Termiticidal activity of $K$. ivorensis stem bark extractives. Means with the same letter for a wood species are not significantly different from each other at $\alpha=0,05$.

Table 3. Termite attack protective rating classifications according to BS EN 2522014.

\begin{tabular}{|c|c|}
\hline & Weight loss classifications \\
\hline Classes & Description \\
\hline $0-5 \%$ & Very durable (very effective) \\
\hline $6-10 \%$ & Durable (effective) \\
\hline $11-40 \%$ & Moderately durable (moderately effective) \\
\hline $41-100 \%$ & Non-durable (non-effective) \\
\hline
\end{tabular}
Source: Antwi-Boasiako et al. 2017

\section{CONCLUSIONS}

K. ivorensis is an indigenous but suitable plantation species whose stem bark traditionally finds continuous medicinal uses for varying conditions. In this study, termiticidal profile of KISB against underground feeding termites was investigated on woods. The phytochemicals' quantities were in the order of total: saponins $>$ tannins $>$ phenol $>$ alkaloids $>$ flavonoids content. KISB demonstrated moderately effective termiticidal activity in particular $5 \%, 10 \%$ and $15 \%$ concentrations (formulations) according to BS EN 2522014 standard specifications. It was therefore concluded that higher formulations above $15 \%$ concentration may not offer protection against termites, hence further biological studies 
using smaller quantity of KISB extract for indoor termites or laboratory tests are recommended.

\section{ACKNOWLEDGEMENTS}

Authors are thankful to International Tropical Timber Organization (ITTO) for financial support through fellowship 009/12S awarded to Gabriel Adetoye Adedeji (GAA). Authors are also thankful to those who contributed to the completion of this work.

\section{REFERENCES}

Abdelgaleil, S.A.M.; El-Aswad, A.F. 2005. Antifeedant and growth inhibitory effects of tetranortriterpenoids isolated from three meliaceous species on the cotton leafworm, Spodoptera littoralis (Boisd). Journal of Applied Sciences Research 1: 234-241.

Abdelgaleil, S.A.M.; Hashinaga, F.; Nakatani, M. 2005. Antifungal activity of limonoids from Khaya ivorensis. Pest Management Science 61 (2): 186-190.

Abdelgaleil, S.A.M.; Iwagawa, T.; Nakatani, M. 2004. Antifungal limonoids from the fruits of Khaya senegalensis. Fitoterapia 75 (6): 566-572.

Adedeji, G.A. 2016. Potential of Khaya ivorensis A. Chev. and Lawsonia inermis Linn. extracts as preservatives for two non-durable woods. Ph.D. Thesis, Department of Forest Resources Management, University of Ibadan, Nigeria. 292 pp.

Ademola, I.O.; Fagbemi, B.O., Idowu, S.O. 2004. Evaluation of the anthelmintic activity of Khaya senegalensis extract against gastrointestinal nematodes of sheep: in vitro and in vivo studies. Vet Parasitol 122: 151-164.

Adesida, G.A.; Adesogan, E.K.; Okorie, D.A.; Taylor, D.A.H.; Styles, B.T. 1971. The limonoids chemistry of genus Khaya (Meliaceae). Phytochemistry 10: 1845-1853.

Adesogan, E.K.; Taylor, D.A.H. 1970. Limonoid extractives from Khaya ivorensis. J Chem Soc (C) 12: 1710-1714.

Adeyemi, S.B.; Afonja, A.I; Ijaduola, A.K. 2014. Phytochemical and nutritional composition of commonly used medicinal plants during pregnancy in Kwara State, Nigeria. International Journal of Phytofuels and Sciences 3(1): 1-19.

Agbedahunsi, JM.; Fakoya, FA.; Adesanya, SA. 2004. Studies on the anti-inflammatory and toxic effects of the stem bark of Khaya ivorensis (Meliaceae) on rats. Phytomedicine 11(6):504-508

Ajayi, O.; Agbola, S.B.; Olokesusi, B.F.; Wahab, B.; Taiwo, O.J.; Gbadegesin, M.; Taiwo, D.O.; Kolawole, O.; Muili, A.; Adeola, M.A.; Olutade, O.G.; Shiji, F.; Abiola, N.A. 2012. Flood Management in an Urban Setting: A Case Study of Ibadan Metropolis. Special Publication of the Nigerian Association of Hydrological Sciences pp. 65-81.

Antwi-Boasiako, C.; Boadu, K.B.; Frimpong-Mensah, K. 2017. Termite resistance of Klainedoxa gabonensis (Kruma), a tropical lesser-utilised-species for commercial utilisation. International Wood Products Journal 8(2): 120-126.

Asamoah, A.; Frimpong-Mensah, K.; Antwi-Boasiako, C. 2014. Efficacy of Erythropleum suaveolens (potrodom) and Distemonanthus benthamianus (bonsamdua) water extractives on the 
durability of five Ghanaian less used timber species of varying perviousness and retentiveness. Journal of the Indian Academy of Wood Science 11 (1): 72-81.

Babajide, J.M.; Atanda, O.O.; Ibrahim, T.A.; Majolagbe, H.O.; Akinbayode, S.A. 2008. Quantitative effect of Piliostigma thionnigii and Khaya ivorensis leaves on the microbial load of dryyam "gbodo". African Journal of Microbiology Research 2: 292-298.

Babajide, J.M.; Babajide, S.O.; Oyewole, O.B. 2007. Survey of Traditional Dry-yam slices (Gbodo) processing operation in South west Nigeria. America-Eurasian J Sustainable Agric 1(1):4549.

BS EN 252. 2014. Field test method for determining the relative protective effectiveness of a wood preservative in ground contact. European Committee for Standardisation, $28 \mathrm{pp}$.

Chan, E.W.C.; Lim, Y.Y.; Chew, Y.L. 2007. Antioxidant activity of Camellia sinensis leaves and tea from a lowland plantation in Malaysia. J Food Chemistry 102: 1214-1222.

Choudhury, M.K.; Boshe, F.D. 2013. Toxicity of Khaya senegalensis (Meliaceae) seed oil against the larvae of Boophilus decoloratus: A One-host tick in Cattle. Proceedings of the Zoological Society 66 (2): 137-140.

Ejikeme, C.M.; Ezeonu, C.S.; Eboatu, A.N. 2014. Determination of physical and phytochemical constituents of some tropical timbers indigenous to Niger Delta area of Nigeria. European Scientific Journal 10(18): 247-270.

Emerhi, E.A.; Adedeji, G.A.; Ogunsanwo, O.Y. 2015. Termites' resistance of wood treated with Lagenaria breviflora B. Robert fruit pulp extract. Nature and Science 13(5): 105-109.

Ewete, F.K.; Bamigbola, K.A. 1998. Effects of three natural products extracts as toxicants against Callosobruchus maculatus F. (Coleoptera: Bruchidae) infesting Bambara groundnut. Journal of Tropical Forest Resources 14: 1-8.

Falodun, A.; Poh, C.D.; Adelusi, S.A.; Emmanuel, O. 2009. Phytochemical and anti inflammatory evaluation of Khaya grandifoliola stem bark extract. Int J PharmTech Res 1(4): 1061-1064.

Hiai, S.H.; Ura, O.; Nakajima, T. 1976. Colour reaction of some sapogenins and Saponins with vanillin and sulphuric acid. Plant Med 29: 116-122.

Iwu, M. 1993. Handbook of African medicinal plants, pharmacognostical pofile of selected medicinal plants. CRC Press Inc pp 196-197.

Ji, K.; Liao, S.; Zheng, X.; NA, Z.; Hu, H., Zhang, P., Xu, Y. 2014. Limonoids from the Fruits of Khaya ivorensis. Molecules 19 (3): 3004-3011..

Kadir, R. 2017. Toxic effects of three selected Malaysian timbers plant extracts against Subterranean termites. Maderas-Cienc Tecnol 19(4): 417-432.

Kale, A.; Gaikwad, S.; Mundhe, K.; Deshpande, N., Salve-Kar, J. 2010. Quantification of Phenolics and Flavonoids by Spectrophotometer from Juglans regia. Int J Pharma Bio Sci 1: 1-4.

Kayode, J.; Jose, R.A.; Ige, O.E.; 2009. Conservation and biodiversity erosion in Ondo State, Nigeria: Assessing botanicals used in the cure of sexually transmitted diseases in Owo Region. Ethnobotanical leaflets 13: 734-738.

Khazaei, J. 2008. Water absorption characteristics of three wood varieties. Cercetări Agronomice in Moldova XLI (2): 5-16. 
Lawal, I.O.; Igboanugo, A.B.I.; Osikarbor, B.; Duyilemi, O.P.; Adesoga, A.A.; Borokini, T.I.; Adeyanju, B.A. 2010. Evaluation of plant-based non timber forest products (ntfps) as potential bioactive drugs in South-western Nigeria. Journal of Clinical Medicine and Research 3(4), 061-066.

Lenz, M.; Creffield, J.W.; Evans, T.A.; Kard, B.; Vongkaluang, C.; Sornnuwat, Y.; Preston, A.F. 2003. International comparison of three field methods for assessing the in-ground resistance of preservative-treated and untreated wood to termites and fungal decay - Summary of observations after five years. IRG/WP 03-20261. International Research Group on Wood Protection, Stockholm, 19 pp.

Lenz, M.; Creffield, J.W.; Evans, T.A.; Kard, B.; Vongkaluang, C.; Sornnuwat, Y.; Lee, C.Y.; Yoshimura, T.; Tsunoda, K. 2011. Resistance of Polyamide and Polyethylene cable sheathings to termites in Australia, Thailand, USA, Malaysia and Japan: A comparison of four field assessment methods. International Biodeterioration and Biodegradation 66: 53-62.

Loko, Y,L.; Dansi, A.; Tamo, M.; Bokonon-Ganta, A.H.; Assogba, P.; Dansi, M.; Vodouhe, R.; Akoegninou, A.; Sanni, A. 2013. Storage insects on yam chips and their traditional management in Northern Benin. Science World Journal 484536 DOI: 10.1155/2013/484536.

Makkar, H.P.S.; Siddhuraju, P.; Becker, K.; 2007. Molecular Biology: Plant secondary metabolites. 1st Edition, Humana Press Inc., Totowa, New Jersey, USA, pp 93-100.

Ogunsanwo, O.Y.; Adedeji, G.A. 2010. Effect of bark extract of Erythrophleum suaveolens (Guillemin \& Perrottet) Brenan on fungal activities in wood of Triplochiton scleroxylon K. Schum. Journal of Environmental Extension 9: 56-62.

Oladimeji, A.; Aliyu, T.H.; Balogun, O.S.; Fabiyi, O.A.; Olatunji, G.A. 2013. Effect of aqueous and n-hexane extracts of Khaya ivorensis A Chev (Meliaceae) on the control of rice seed-borne fungi. Nigerian Journal of Agriculture Food and Environment 9(1): 72-75.

Olajuyigbe, S.O.; Ogunsanwo, O.Y.; Adegeye, A.O. 2010. Compressive strength in heartwood Extract of Teak (HWE) treated hardwoods after exposure to white rot attack. International Journal of Biological and Chemical Sciences 4(3): 571-578.

Olayinka, O.A.; Onoruvwe, O.; Loti, T.Y. 1992. Cardiovascular effects in rodents of the methanolic extract of the stem bark of Khaya senegalensis A. Juss. Phytother Res 6: 282-284.

Olusola, J.A.; Oyeleke, O.O. 2015. Survey and documentation of medicinal plants in Wildlife Park of Federal University of Technology, Akure, Nigeria. International Journal of Life Sciences Research 3 (1): 238-246.

Omole, A.O.; Onilude, M.A. 2000. Study on use of engine oil as wood preservative. Journal of Tropical Forest Resources 16 (1): 66-71.

Oshunsanya, S.O. 2013. Predicting saturated hydraulic conductivity from selected properties of Alfisol using Pedo-transfer functions - a case study of the Iwo sandy loam, Ibadan, southwest Nigeria. Ife Journal of Science 15(1): 135-143.

Padmaja, G. 1989. Evaluation of techniques to reduce assay-able tannin and cyanide in cassava leaves. J Agric Food Chem 37: 712-716.

Satti, A.A.; Elamin, M.M. 2012. Insecticidal activities of two Meliaceous plants against Trogoderma granarium Everts (Coleoptera: Dermestidae). International Journal of Science and Nature 3 (3): 696-701.

Singh, D.K.; Srivastva, B.; Sahu, A. 2004. Spectrophoto-metric determination of Rauwolfia alkaloids, estimation of reserpine in pharmaceuticals. Analytical Sci 20: 571-573. 
Stephen, U.A.; Abiodun, F.; Osahon, O.; Ewaen, E. 2009. Phytochemical analysis and antibacterial activity of Khaya grandifoliola stem bark. Journal of Biological Sciences 9 (1): 63-67.

Syofuna, A.; Banana, A.Y.; Nakabonge, G. 2012. Efficiency of natural wood extractives as wood preservatives against termite attack. Maderas-Cienc Tecnol 14(2): 155-163.

Taiwo, E.A.; Ogunbodede, R.A. 1995. Production of tannin adhesives from bark of Nigerian trees. Wood Science and Technology 29: 103-108. DOI: 10.1007/BF00229339.

Taylor, D.A.H. 1977. The structure of an extractive from Khaya ivorensis. Phytochemistry 16 (11): 1847-1849.

Tepongning, R.N.; Lucantoni, L.; Nasuti, C.C.; Dori, G.U.; Yerbanga, S.R.; Lupidi, G.; Marini, C.; Rossi, G.; Esposito, F.; Habluetzel, A. 2011. Potential of a Khaya ivorensis - Alstonia boonei extract combination as antimalarial prophylactic remedy. Journal of Ethnopharmacology 137: 743-751.

Tepongning, R.N.; Yerbanga, S.R.; Dori, G.U.; Lucantoni, L.; Lupidi, G.; Habluetzel, A. 2013. In vivo efficacy and toxicity studies on Erythrina and Khaya ivorensis used as herbal remedies for malaria prevention in Cameroon. European Journal of Medicinal Plants 3 (3): 454-464.

Vanucci, C.; Lange, C.; Lhommet, G.; Dupont, B.; Davoust, D.; Vauchot, B.; Clement, J.L.; Brunk, F. 1992. An insect antifeedant Limonoids from seed of Khaya ivorensis. Phytochemistry 31: 3003-3004. DOI: 10.1016/0031-9422(92)83435-2.

Zhang, B.; Yang, S.P.; Yin, S.; Zhang, C.R.; Wu, Y.; Yue, J.M. 2009. Limonoids from Khaya ivorensis. Phytochemistry 70: 1305-1308. 